\title{
Social economy indicator on constructing forest sustainability in Bali
}

\author{
Putu Krisna ADWITYA SANJAYA, \\ I Putu NURATAMA, \\ Gede Indra SURYA DIPUTRA
}

Faculty of Economics Bussines and Tourism, Universitas Hindu Indonesia, Jln. Sanggalangit, Tembawu, Penatih, Denpasar, Bali 80238, Indonesia

\begin{abstract}
Forestry issue has ever been discussed in conference of United Nation Framework Convention on Climate Change about deforestation that happens because industrialization that oriented toward economical growth and ignores environment aspect that can cause global warming. In Bali, sustainability has been a pplied since long time ago. It can be proved by the existence of tumpek wariga that makes an appreciation respect directly to the plants is an embodiment of environmental sustainability as a manifestation of local wisdom. This is insufficient remember the fact that the condition of Bali's forests has been distorted. This analysis aims to know the simultaneous and partial influences and the most dominant determinants affecting forest sustainability. Within the lifetime data and analysis of adaptive partial adjustment model double $\log$, this analysis found the fact that simultanousely and partially Domestic Product Regional Bruto, the amount of citizen, regional autonomy policy and forest sustainability condition on previous year has significant influence toward forest sustainability during the period of this analysis. The amount of citizen variable is the most dominant variable toward forest sustainability because it obtains the highest standardized of coefficient data of 0,292. Based on the analysis, result and discussion, forest have to be well maintained, conserved and utilized in balance for all the people prosperity in current generation and for the sake of next generation. Correct management needed for development sustainability especially in long-term capacity through internalization and negative externalization which caused by economical development.
\end{abstract}

Keywords: Domestic Product Regional Bruto, The Amount of Citizen, Regional Autonomy, Local Wisdom, Partial Adjustment Model. 
Sumario:

I. Introduction.

II. Research methodology.

III. Result and discussion.

IV. Conclusion and implication.

V. Reference.

Recibido: agosto 2020.

Aceptado: octubre 2020. 


\section{INTRODUCTION}

Natural resource is environment important aspect. Human live and grow within the benefit of natural resources around them such as land, water, air, flora, fauna, microorganism, mineral and energy (Sikor et al., 2010). On the issues of global warming which causes world limate change, natural resource factor especially forest become the main focus to reduce the effect of global warming (Sunderlin et al., 2014). Thus, it indicates the important of forest for human life. Forest has various function based on economical development, which forest was free sector back then.

In Bali, the topic of environment rescue had been an old heritage since long time ago. It can be shown by the existence of particular ritual which called tumpek wariga sebilang enem sasih that has a purpose to appreciate the existence of flora which indirectly becomethe source of environment conservation. Besides, through the concept of Tri Hita Karan, an orientation of concept on human relation with other human, environment and God become an important issue from the old day until now. In Bali tradition, there is a place called alas angker to regularly maintain Forest Sustainability, and there is also pakelem on forest or mountain. Total forest are of Bali is 130.686 .01 hectares it divided on 8 district and city, except Gianyar district which has no forest at all. Those forest is $23,20 \%$ from total area of Bali (Badan Pusat Statistik Provinsi Bali, 2013)

Tabel 1. Total Area of Forest on each district 2019.

\begin{tabular}{|c|c|c|c|c|c|}
\hline \multirow[t]{2}{*}{ City/District } & \multirow{2}{*}{$\begin{array}{c}\text { Total } \\
\text { Area } \\
\text { (ha) }\end{array}$} & \multirow{2}{*}{$\begin{array}{c}\text { Total } \\
\text { Forest } \\
\text { (ha) }\end{array}$} & \multicolumn{3}{|c|}{$\begin{array}{c}\text { Percentages of Forest compared } \\
\text { to total area } \\
\end{array}$} \\
\hline & & & $\begin{array}{c}\text { District } \\
(\%)\end{array}$ & $\begin{array}{c}\text { Province } \\
(\%)\end{array}$ & $\begin{array}{c}\text { Forest } \\
\text { Province } \\
\text { (\%) }\end{array}$ \\
\hline Jembrana & 84.180 & $42.156,27$ & 50,08 & 7,48 & 32,26 \\
\hline Tabanan & 83.933 & $9.969,15$ & 11,88 & 1,77 & 7,63 \\
\hline Badung & 41.852 & $1.779,87$ & 4,25 & 0,32 & 1,36 \\
\hline Gianyar & 36.800 & - & - & - & - \\
\hline Klungkung & 31.500 & $1.048,50$ & 3,33 & 0,19 & 0,80 \\
\hline
\end{tabular}




\begin{tabular}{|c|c|c|c|c|c|}
\hline Bangli & 52.081 & $9.341,28$ & 17,94 & 1,66 & 7,15 \\
\hline Karangasem & 83.954 & $14.220,23$ & 16,94 & 2,52 & 10,88 \\
\hline Buleleng & 136.588 & $51.436,21$ & 37,66 & 9,13 & 39,36 \\
\hline Denpasar & 12.398 & 734,50 & 5,92 & 0,13 & 0,56 \\
\hline Provinsi Bali & 563.286 & $130.686,01$ & - & 23,20 & 100,00 \\
\hline
\end{tabular}

Sumber : Dinas Kehutanan Provinsi Bali, 2019

Forest condition in Bali experienced a big pressure by the distruction of forest safety, it reduce the area of forest and improve critical land of Forest in Bali, which influence the macro climate condition in Bali by improved the heat of weather, and the lack of water in water resources because tere are many forest distructed in Bali. This distruction caused by several factors, such as forest other function as people living area and human irresponsible action which caused a wild fire on forest. It also can be caused by illegal logging and forest product illegal taking.

One of important factors that have to be faced to create further development is how people should rescue their environment without sacrifice economical development and social justice (Blowers, 1993). For several people, further development of forest related to economical development and how to looking for a way to improve an economical condition for long-term without spending any natural resources. Successful economical development will improve people ability to protect their environment. Economical development of an area is another type of effort to improve human life. Indicator that can be used to understand an economical condition of area is the development of Domestic Product Regional Bruto and each capita value development of an area (Sanjaya, 2018). Increasement of people growth and people economical condition become the pressure toward natural resources increase as well. The increasement of people growth demand people to improve their basic needs and superior needs. This need improvement makes human within allhis roles and capacity used natural resources potential and environment as practical strategy on fulfilling their needs. This motivation and exploitation of resource will obtain a big impact on natural resources demand and environment. Furthermore, it will be more impactful if there is a regional autonomy regulation which has double knife system that carried out to improve people social life based on the culture in the other hand, it will destroy the environment conservation.

As one of development strength, Forest Sustainability need to be correctfully maintained, petantially improved on it qualities (Subandi, 2016). Bali has inheritaed program of environment conservation since long time ago. It can be proved by the existence of tumpek wariga ritual every sixth month on Bali calendar and the implementation of wana kerthi. Those ritual still not enough to 
prevent environment distruction remind that Bali forest also had distortion of safety, the area of forest reduced, and critical land in forest area increased. Furthermore, the development of social economy indicator has brought a big influence toward forest preservation. Therefore, it need scientific knowledge related to Forest Preservation which expected to become the basic knowledge of making policy, thus, sawala of economic social justification will not be crucial issues toward environment. This is the new concept of this analysis, which is supported by empirical data, contributing social variable, developing the concept of dummy variable and using an analysis model of Partial Adjustment Model (PAM). Moreover, this analysis become an urgent analysis because it has a purpose to analyze the influence of Domestic Product Regional Bruto, the amount of citizen, regional autonomy and Forest Sustainability in previous periode simultanousely and partially, and it has a purpose to understand what kind of variable that dominantly influence the Forest condition in Bali.

\section{RESEARCH METHODOLOGY}

The data used here, is secondary data which has obtained during 1993 to 2019. Argumentation used from 1993 as the first year of data, the amount of earliest requirements in data testing, while 2019 is the lattest year that exist based on the data. Another data sources in this analysis is primary data and another secondary data. Primary data comes from the result of adjustment publication and the description by other related instances, arranged interview with the informant such as government towrd the organization of regional instrument such as: Statistical Main Instantion, Development Plan and Regional Development Instantion, Environmental Instantion, Forestry Instantion, Stakeholders, Bali Environmental Facilities, Bali Greenpeace Committee. Another secondary data taken by Domestic income regional bruto which obtained from the official publication of mainstatistical institution of Bali, Forestry institution of Bali and the detail will be included: the data of total forest area and the amount of forest that has been distructed by forestry institution sand the data of people which obtained from BPS publication of Bali.

This research used interpretation of Forest Sustainability which counted the forest that has no distruction. This research used and application of econometric dynamic model Distributed Lag within the technique of double log on Forest Sustainability of Bali was carried out by computer application software eviews 9.0 (Winarno, 2011). Before regression model testing, need to do the test toward data stationerity of time with stationerity test, cointegrity test, continued to basic assumption test (such as linearity test and normality test) then classical assumption test (multicolinerity test, heteroscedacity test and autocorrelation test) in order to make the model become Best Liniear Unibiased Estimator 
(Ghozali \& Ratmono, 2017). Data analysis technique used here is regression analysis Linear Partial Adjustment Model within the method of double log to know the influence of independent variable toward dependent variable, the $\mathrm{ec}=\mathrm{xample}$ will be explained as below:

$$
\operatorname{LnY}_{\mathrm{i}}=\beta_{0}+\beta_{1 \mathrm{Ln}} \mathrm{X}_{1 \mathrm{i}}+\beta_{2 \mathrm{Ln}} \mathrm{X}_{2 \mathrm{i}}+\beta_{3 \mathrm{Ln}} \mathrm{X}_{3 \mathrm{i}}+\beta_{4} \mathrm{X}_{4 \mathrm{it}-1} \mathrm{e}_{\mathrm{i}}
$$

Description:

$$
\begin{aligned}
\operatorname{LnY}_{\mathrm{i}} & =\text { Forest Sustainability from } 1993 \text { to } 2019 \\
\operatorname{LnX}_{1 \mathrm{i}} & =\text { Domestic Product Regional Bruto } \\
\operatorname{LnX}_{2 \mathrm{i}} & =\text { The amount of citizen } \\
\operatorname{LnX}_{3 \mathrm{i}} & =\text { Regional Autonomy Policy } \\
\operatorname{LnX}_{4 \mathrm{i}-1} & =\text { Forest Sustainability in previous year } \\
\beta_{1}, \beta_{2}, \beta_{3}, \beta_{4}= & \text { Coefficient Regression } \\
\beta_{\mathrm{o}} & =\text { Intersep } \\
\mathrm{e}_{\mathrm{i}} & =\text { erorr term estimation } \\
\mathrm{i} & =\text { Observation }-\mathrm{i}
\end{aligned}
$$

\section{RESULT AND DISCUSSION}

\section{Validity test Time Series}

The data used here need to get calidity test which include stationary test and cointeration test.

\section{Stationer test}

Stationer test used to know the characteristic of data in observation, where the data expected to have low variance that not really far from it means number.

Tabel 2.- Stationer test result

\begin{tabular}{|l|c|c|c|c|c|}
\hline \multicolumn{1}{|c|}{ Variable } & ADF Score & \multicolumn{3}{|c|}{ McKinnon Critical Score } & Information \\
\hline & & $\mathbf{1 \%}$ & $\mathbf{5 \%}$ & $\mathbf{1 0 \%}$ & \\
\hline Forest Sustainability & -3.565 & -3.724 & -2.986 & -2.632 & Stasioner in ordo (1) \\
\hline DPRB & -4.916 & -3.724 & -2.986 & -2.632 & Stasioner in ordo (1) \\
\hline People amount & -4.726 & -3.724 & -2.986 & -2.632 & Stasioner in ordo (1) \\
Autonomy Policy & -5.000 & -3.724 & -2.986 & -2.632 & Stasioner in ordo (1) \\
Forest Sustainability & -3.494 & -3.737 & -2.986 & -2.632 & Stasioner in ordo (1) \\
\hline
\end{tabular}

Sumber: Analysis Result, 2020 
Based on stationer data test in table 2, it can be concluded that all the data currently in stationer condition. It can be seen by the ADF (Augmented Dickey Fuller) score which smaller than critical score of McKinnon on signification 5 percent.

\section{Cointegration Test}

Cointegration test is important on developing model of econometric dynamic. Thus, the interpretation toward model will not be mistaken, especially for longterm analysis. Cointegration test result will be explained on table 3 that indicated how variable of foreign investment have cointegration with the entire independent variable. It can be seen by the valueof Likelihood ratio that bigger than critical value within the level of 5 percent.

Tabel 3. Cointegration Test Result by Johansen test between Forest Sustainability variable and each independent variable

\begin{tabular}{|c|c|c|c|c|}
\hline $\begin{array}{c}\text { Independent } \\
\text { Variable }\end{array}$ & Eigenvalue & $\begin{array}{c}\text { Likelihood } \\
\text { Ratio* }\end{array}$ & $\begin{array}{c}\text { Critical Value } \\
\mathbf{5 \%}\end{array}$ & Information \\
\hline DPRB & 0.478 & 16.589 & 15.49 & Interval lag 1 to 2 \\
\hline The amount of citizen & 0.286 & 19.930 & 15.49 & Interval lag 1 to 2 \\
Autonomy Policy & 0.187 & 17.990 & 15.49 & Interval lag 1 to 2 \\
Ln Yt-1 & 0.700 & 28.903 & 15.49 & Interval lag 1 to 2 \\
\hline
\end{tabular}

Source: analysis result,2020 / Information: * Likelihood Ratio = Trace Statistic.

\section{Classic Assumption Test}

1) Normality Test

Normality test has a function to test the significance between independent variable and dependent variable through $t$ that will only be valid if it distributed reducial counted as normal (Wijarjono, 2015). This analysis using the model of Jarque-Bera (J-B) compared J-B with it probability. Based on the data processing, it is known that Jarque-Bera value is 1205 with probability level of 0,547 which means probability value is more than the actual level used ( 5 percent). This means that the data has been normally distributed. 
2) Linerity Test

Linerity test used to observe whether the variable of this analysis has linear correlation or not significant. Linearity test of this analysis used Ramsey test, which comparing the significant value with actual level used (5 percent). It indicated the probability score of 0,246 and it is bigger than the actual level which is 0,005 which means estimated specification model is linear within trust level of 95 percent.

3) Multicollinearity Test

Multicollinearity test in this analysis done within Klien test model which compare lower cases (correlation between each independent variable) if $\mathrm{R}^{2} \mathrm{y}$ $\mathrm{Xi}, \mathrm{Xj} \ldots . \mathrm{Xn}>\mathrm{r}^{2} \mathrm{Xi}, \mathrm{Xj} \ldots . \mathrm{Xn}$ thus, there are no multicollinearity happen in this analysis. based on the test output, it is explained that double coefficient linier determination value $\left(\mathrm{R}^{2}=0.989\right)$ bigger than coefficient determination result of all regression auxillary for domestic product regional bruto $(0,905)$, the amount of citizen $(0,967)$, regional autonomy policy $(0,814)$ and Forest Sustainability in previous year $(0,981)$, it can be concluded that there is no multicollinearity problem inside the model.

4) Heteroscedasticity Test

Heteroscedasticity test has a purpose to observe is there any unbalance variance inside the model of one observation to another observation. In this analysis, Heteroscedasticity was done by using the model of Harvey test that compared the probability value and it actual level used. Probability value has to be bigger than probability significance of 5 percent to make the model indicated as has no Heteroscedasticity. This model obtained 0,354 for variable domestic product regional bruto, 0,201 for variable of the amount of citizen, 0,953 for variable regional autonomy policy and 0,081 for variable Forest Sustainability in previous period. It can be concluded there are no heteroscedasticity problem of this model.

\section{5) Autocorrelation Test}

This analysis used Langrage multiplier test to analyse if there is any autocorrelation problem of this analysis or not. This model obtained the value of Obs* $R$ Square 0.230 bigger than the actual level of 5 percent, it means that this model did not contain autocorrelation problem. 


\section{Distributed Lag Estimation Result}

In this part of analysis, the model used is econometric dynamic distributed lag within the support of software Eviews 9.0. This analysis model has a purpose to understand the influence of domestic product regional bruto, the amount of citizen, regioanal autonomy policy and Forest Sustainability in previous year toward Forest Sustainability in Bali 1993 to 2019, whether it simultanousely or partially. The summary of data analysis result using Eviews 9.0 can be seen on table 4 below.

Table 4. The estimation of Bali Forest Sustainability in 1993 to 2019

\begin{tabular}{|c|c|c|c|}
\hline Variable & Coefficient & t Statistic & Sig \\
\hline DPRB & 0.047 & 2.712 & 0.044 \\
\hline People & 0.064 & -3.068 & 0.027 \\
$\begin{array}{c}\text { Autonomy } \\
\text { Policy }\end{array}$ & 0.013 & 1.632 & 0.042 \\
\hline Forest t_1 $_{r}$ & 0.053 & 4.208 & 0.034 \\
\hline \multicolumn{2}{|c|}{ Constant $=\mathbf{1 1 . 7 6 2}$ F Statistic $=\mathbf{5 1 7 . 2 7 0}$} \\
R Square $=\mathbf{0 . 9 8 9}$ & Sig $=\mathbf{0 . 0 0 0}$ \\
\hline
\end{tabular}

Sumber : Analysis Result, 2020

\section{The Influence of the entire variables for short-term capacity}

Simultanousely, all the included variable such as Domestic Product Regional Bruto, the amount of citizen, regional autonomy policy and Forest Sustainability has positive and significant influence toward Forest Sustainability in 1993 to 2019. Statistc test result showed that significant has been reach the actual level of 95 percent. Economcal growth is a process, not just temporary description of current economical condition. Regional and sectoral development should be done together in order to make sectoral development in every region can be implemented based on it potential and regional priorities. Domestic Product Regional Bruto is the amount of additional value of every ussines and services area of a region, applied the entire amount of goods and services produced by every economic unit. Every country has been agreed that to measure economic prosperity of a nation, the indicator used would be related to the value of product national bruto each capita (Suparmoko, 2016). Higher the amount of Product National Bruto (PNB) each capita, thus the more prosperous a nation is. However, the latest development of balance organization concept to obtain 
the indicator of nation prosperity needs to be calculated by depreciation of natural resources and environmental degradation. Development policy that has a knowledge of environment, it needs a policy that include enabling policy (Prabowo, Bachri, \& Wiwoho, 2017) Is it being realized or not, the era of decentralization, Indonesia developmental thinking has been moved from justice and balance to centralization governmental system. Related to the increasement of citizen, there will be higher demand of goods and services to fulfill their daily needs. The increase nuber of goods and services will need more natural resources to be producted. High growth of people can cause natural resources degradation because there are many forest area will be used as people living place.

The relation between the amount of citizen, economical growth, and environmental resources can be simply described by how people will develop, their economical condition will develop, and the demand of good and services also increase to maintain the level of people live in a nation. However, if this demand of product needs increased, natural resources will experiences degradation, besides within the economical development, environmental pollution will be increased. Furthermore, it can be concluded economical development will caused two sides of effect, positive effect will be related to human life, there will be much value of goods and services, people will easier to obtain their daily needs. In the other way, negative effect will influence an environment. There will be much pollution, and natural resources will be decreased.

\section{The Influence of Domestic Product Regional Bruto toward Forest Sustainability in Bali 1993-2019}

Coefficient estimation value of Domestic Product Regional Bruto (DPRB) $\hat{\beta}_{1}=0.047$ It means that domestic income regional bruto has increased for a thousand, thus, Forest Sustainability in Bali will be increased for 0,047 percent within the other independent variable include as constant. It applied for the opposite; if the domestic income regional bruto decreased for a thousand, thus Forest Sustainability will e decreased for 0,047 percent within the assumption of other independent variable is constant. This analysis obtained a result of significant and positive influence between Regional income toward Forest Sustainability in Bali. This is in line with the analysis of Panto (2003) which showed that Forest nd it various kind of function happen not only economical side but also environmental side that has very important role on development process. Related to the analysis of Simon Kuznets regarding environmental conservation has an influence toward economical development which theoretically emergence the theory of Environmental Kuznets Curve (EKC). 
This theory explained regarding the development of technology, developing country tends to experience natural resources degradation while developed country, did not experienced any natural resources degradation even if they followed by the development of technology. Based on that finding, the curves for Environmental Kuznets Curve is reversed U letter (Gupito, 2012) The right method to reduce the unbalance between growth and economical development toward environmental quality is to develop an economical growth based on environmental knowledge and appy the concept of sustainable development. Economical development within environmental based is a sustainable development concept which is not only concern on short-term capacity but also have a concern for long-term capacity and future oriented that consider about the balance between economical development and environmental conservation which is indicated by zero sign of social distruction and natural distruction (Gupito, 2012). Therefore, economical development based on environmental knowledge is one way to solve the problem on natural distruction during economical development in several developing countries.

\section{The Influence of amount of citizen toward Forest Sustainability in Bali 1993-2019}

Coefficient estimation value of total citizen $\hat{\beta} 2=0.064$ It means that if the amount of citizen increased by million, therefore Forest Sustainability in Bali will increase 0,064 percent within the assumption of another independent variable is constant. Dynamic between people development and deforestation is not a novel issue, several studies claim that people development is the caused of defosteration in Indonesia (Hosonuma et al., 2012; Margono et al., 2012). This case make sense because the amount of citizen in Indonesia almost 250 million people in 2013 within the high population rate, 1,7 percent each year (BPS Data, 2018) Citizen is the main factor of Forest Sustainability. Rin line with the analysis of Krisna et, al (2018) that human live together with the environment including forest. Most cases indicated that many people used forest at their house, and it threatens forest sustainability. However, people in Bali are different; they are tends to get along well with nature ad forest. There are many people in Bali who has a place close to the forest, but they not tried to harm it forest, they tried to maintain the forest sustainability and living under natural balance. Related to people traditional culture, Bali live within the term Tri Hita Karana means there should be a balance of relation between human and their environment. In Hindu religion, they have belief that balance between human and environment should be obtained by human effort on religious action and ritual for environment God. 
A research by Sunderlin \& Resosudarmo (2014) supported that people high rate population will cause the demand of new land, whether it for place to stay or for economical activities, Forest area become the main target of this demand. However, the opinion of population as the only cause of forest degradation is not totally right. Many other aspects behind the high population growth that contribute to deforestation need to be explored further. Basically, on interpreting causality correlation between human and environment based on Vedas (scripture) and Hindu basic framework called Tattwa, Susila and Acara. Tattwa thought provide a deep philosophical thinking regarding it main belief and forestry concept. Susila thought is a framework to behave based on norm, and Acara is a framework to connect oneself with Ida Sang Hyang Widhi Wasa within the traditional ritual as it basic law. Whoever and whenever it is, human purpose of life is to obtain physical and spiritual happiness. Hindu holy people formulated their life purposes withi Moksartham Jagadhita Ya Ca Iti Dharma. More detail, they believe there are human life purposes which called Catur Purusa Artha (Dharma, Artha, Kama, Moksa) and three main causes of happiness called Tri Hita Karana (Parhyangan, Pawongan, Palemahan) which contain the principle of regional development in Bali.

To manifest those purposes of life, Hindu taught four lifestyle called Catur Marga which contain of Jnana (wise thinking), Karma (work based on norm), Bhakti (full of love) and Yoga (discipline life). It should be realized that the environmental burden in supporting development will be heavier and harder. Natural harmonization will be more real and quite fast to reach an irreversible point if people did not become friendlier toward environment. If point of disharmony has reached a clear climax, the power of natural production will not be restored, and there will be misery. To be able to preserve the environment, it is necessary to raise public awareness, human have to be aware and no longer desire to conquer nature and its surroundings. Utilization of natural resources must be based on policy of maintaining harmony and balance.

\section{The Influence of Regional Autonomy Policy toward Forest Sustainability in Bali 1993-2019}

Statistical analysis result of regional autonomy policy has been known that $t$ value include as positive of 1.632 smaller than critical value $t$ of 1.721.The results of the $t$ test statistics for regional autonomy policy obtained a significance value of 0.042 which is smaller than the error rate $\alpha=0.05$ Thus, it can be concluded that regional autonomy policy did not has significant influence toward forest sustainability in Bali 1993-2019. Nowadays, forestry policy developments are experiencing ups and downs due to pressure from inside 
and outside the country. There are several problems regarding the forest which causes some new issues. Because forestry problems are not only about forest and land conversion but also about other elements such as social, economic, and even political conflicts. National strategy for forestry management until today still not able to meet the clear vision and mission as a result of spatial planning that has not been completed Thus, it can caused further conflicts and problems. The impact of decentralization of forestry policies in the era of regional autonomy has generally not shown the expected results. The distribution of authority to local governments has caused the emergence of stigma and shifting mindset where it increasing local incomes is main priority when they obtain a great responsibility to manage their own regions without financial support from the central government to maintain their activities. In the other hand, unclear definitions of administrative authority and incomprehenve understanding among central government, province and district toward decentralization tend to be obstacles of regional forest development. Moreover, the authority for Regional government whether it from Mayor or Regent to make forest management licenses for private sector has made a significant contribution to regional efforts on increasing Regional Original Income. However, as the arises concern regarding the extent of degraded forests due to forest exaggerated use that carelessly avoid the rules of sustainability and only concern with it economic benefits. Even though the local people is the main target of empowerment effort in the era of regional autonomy, in reality the local people has not received aby reasonable and sustainable benefits.

\section{The Influence of Forest Sustainability in Previous year toward Forest Constancy in Bali 1993 - 2019}

Statistical fincing for Forest sustainability in previous year indicated that $\mathrm{t}$ value has positive score of 4.208 which is bigger than critical value $t$ table of 1.721. Statistical analysis result $t$ test of forest sustainability in previous year gain the significant of 0,034 which is smaller than the error rate of $\alpha=0,05$, thus it can be concluded that the previous sustainability has positive and significant impact toward forest sustainability in Bali 1993-2019. The obtained result of this analysis regarding an influence of forest sustainability in previous year toward fores sustainibility in current year in Bali related to the theory that stated there is a positive and significant impact on forest constancy on previous year oward current forest susainability in Bali, therefore, it indicated that the previous forest sustainability can be used for this current era within the notes that people keep maintain it sustainability. Conception of Hindu teaching Tri Samaya especially Atita or the past carried out important role on making decision on organizing the plan of forest sustainability policy. It is proved 
through the observation of regression coefficient variable of previous year forest sustainability with positive value of 0,053 which is interpreted if the previous sustainability increased by 1 hectare are, the current sustainability of forest in Bali will experienced an increase by 5,30 percent within the assumption of independent variable assumption include as constant. in the other word, the current forest sustainability is influenced by previous year condition. current condition (Wartamana) is reality owned by people and Nagata (future condition) influenced the plan, because current organized planning can be used to know future opportunities, predict the upcoming obstacles and decide the plan to overcome every obstacles to create sustainability.

\section{The Amount of Citizen as Dominant Variable which influenced Forest Sustainability in Bali 1993-2019}

Based on the value of standardized of coefficient beta can be known that variable of total citizen is the most influenced variable on this analysis with standardized of coefficient beta value of 0,292. Compared to other three variables 0,037 (DPRB), 0,053 (previous year sustainability) and 0,028 for regional autonomy. The quality of environment will be well maintained if human able to manage the carrying capacity of limit between the minimum and optimum. Organizing capacity below the minimum is a condition of resources are not used properly, whereas if it approaches or exceeds the maximum carrying capacity there will be risk happen to environment, such as environmental pollution. The carrying capacity of environment will be optimally functioned if it did not have any population pressure on environment, in other words the population amoun and the available resources in the environment are balanced. This condition is hardly found in developing country. The reality faced by developing countries in general is that, urban environment gained large population pressure while rural areas, resources are not optimally functioned. People are the main actor of environment sustainability. It is in line with the analysis of Krisna (2018) which explained that human life side by side with environment including forest. Hindu religion also taught them about environment conservation. Humans may have a rule over nature, regulate, occupy and enjoy within the conditions of it devotion. Bhakti is compassion realized in the form of Yadnya. Make sure the environment harmonious is clearly the obligation and needs of Hindus. Inside Atharwa Weda XII:1 explained that:

Satyam brhad rtam naram diksa tapo brahma yajnya prthirviam dharayanti

Likewise in the Tri Sandya mantra explained that: 
Om bhur bhvah swah

Om Narayana evedam sarwam yad bhutam yasca bahwyam Mahadewa sarvaprani hitam karah

This means:

Om is an earth, sky and air.

Narayana is all of this, which has been exist and will be there Mahadewa give grace to all beings

Thus, damaging and polluting environment means insulting God. Inside lontar agastya parwa and Arjuna Wiwaha (Hindu Traditional Literature) explained that there are three actions which cause happiness for people. Those three actions called as Tapa, Yadnya and Kirti. Tapa means life under control means and holding fast to the truth, Yadnya means sacrificing their ego and Kirti means doing real work to create a harmonious relationship among God, human and nature. Related to those explanations, there are six kirti that has to be applied on this universe conservation 1) Jagat kirti (earth conservation), 2) Samudera kirti (marine conservation), 3) Danu kirti (lake conservation), 4) Jana kirti (preservation among humans), 5) Atma kirti (self-conscious) and 6) Wana kirti (Forest Conservation). Besides Hindu religion concept about life purposes, environmental conservation (forest) which applied on every religion literary text, rituals that specifically correlate with nature conservation are also performed such as the Bhuta Yadnya ritual which is intended to harmonize and purify the universe to reach Bhutahita or Jagadhita. According to Hindu the basic elements that build nature called as Panca Maha Bhuta (Pertiwi, apah, teja, bayu dan akasa). Panca Maha Bhuta formed by a subtle element called Panca Tan Mantra which consists of gandha (smell), rasa (taste), sparsa (light), appearance (form), sabda (sound). This taught is foundation of love toward natural environment in Hindu. Bali is the right place to obtain those concepts. The concept of Segara-giri or pasir ukir, Padma Bhuwana until Tri Hita Karana, Tri Mandala, Tri Angga and other Hindu teachings, this is the argument which underlying in Bali that population is dominant variable that influences forest preservation.

\section{The Influence of All Variables in Long-Term Capacity}

For coefficient constant and long-term coefficient, counted by the amount of regression in short-term coefficient divided by $\delta$ which $\delta=(1-0.053)=0.947$, $\delta=0.947$ is an adjustment coefficient means a participated coefficient of Forest Sustainability similar with the estimation Forest Sustainability. In this case, it needs an adjustment time of $0,947 \times 12$ months $=11,36$ months $=341$ days . 
Contribution of natural resource for economical development until 1930 explained that a region economical condition in one area or development of people in one area can be seen by how much those areas owned natural resources. Until today, there is still much opinion that stated the country experienced proverty because they experienced lack of natural resources. It is true that the limitation of low income in one country because there are not ebough resources whether it based on quality or quantity. Contribution of natural resource will become lower, but based on the reality, if a country have more advanced in economical way based on wuantity, thevariant of it natural resource will change from potential natural resource to real natural resource. because factually, there will be more concern regarding economical growth and economical development, there are moch natural resources which need to be processed, and it will reduce the existing natural resources, especially non-renewable resources, however renewable resource will be harder to get. Though it renewable, if this resources keep being used, and they not carefully used it, thus natural resources will become rare item. Moreover, the entire activities of Forest Sustainability can not be separated with the aspect of planning that deciding what activities they should done for the future, it also need strategic, rational and measured consideration. Thus, Economic social growths will not distructed any aspect of Forest Sustainability and it is relatable within the concept of sustainable development and environmental based.

\section{CONCLUSION AND IMPLICATION}

\section{Conclusion}

The result of this analysis showed that simultaneously and partially, Domestic Product Regional Bruto, the amount of citizen, regional autonomy policy and Forest Sustainability from previous year has significant influence toward Forest Sustainability in Bali 1993 to 2019 within the trust level of 95 percent. Variable of people number is a determinant that has dominant influence on Forest Sustainability in Bali that carried out the value of standardized of coefficient beta with highest number pf 0,292 .

\section{Implication}

Forest as the source of development has real benefit for human life, whether it ecologically, social culture or economic in dynamic way. Therefore, people needs to take a good care of forest, protect it and used it well, have a responsibility for all the people life prosperity in Indonesia wheteher it for current generation or future generation. Natural resources management and it relation with environment 
not only considered based on it benefit for temporary resource, but also based on it benefit for long-term capacity. It can be done by internelization of negative externality which caused by economical development and strong commitment to conserve the forest. Thus, it will be related to governmental vision of Bali which called as Nangun Sad Kerti Loka Bali.

\section{REFERENCE}

- BADAN PUSAT STATISTIK PROVINSI BALI. (2013). Bali dalam Angka 2013. In BPS Provinsi Bali.

- BLOWERS, A. (1993). Planning for a sustainable environment. Planning for a Sustainable Environment. https://doi.org/10.1016/0264-8377(94)90032-9.

- GHOZALI, I., \& RATMONO, D. (2017). Analisis Multivariate dan Ekonometrika: Teori, Konsep dan Aplikasi dengan menggunakan EViews 10. In Badan Penerbit Universitas Diponegoro.

- PRABOWO, D. P., BACHRI, S., \& WIWOHO, B. S. (2017). PREDIKSI PERUBAHAN PENGGUNAAN LAHAN DAN POLA BERDASARKAN CITRA LANDSAT MULTIWAKTU DENGAN LAND CHANGE MODELER (LCM) IDRISI SELVA 17: STUDI KASUS SUB-DAS BRANTAS HULU. Jurnal Pendidikan Geografi. https://doi.org/10.17977/um017v22i12017 p032.

- SANJAYA, K. (2018). Metode Mudah Memahami Pengantar Ekonomi Makro. Denpasar: Penerbit Dharmastuti.

- SIKOR, T., STAHL, J., ENTERS, T., RIBOT, J. C., SINGH, N., SUNDERLIN, W. D., \& WOLLENBERG, L. (2010). REDD-plus, forest people's rights and nested climate governance. Global Environmental Change. https://doi.org/ 10.1016/j.gloenvcha.2010.04.007.

- SUBANDI, M. (2016). Ekonomi Pembangunan.

- SUNDERLIN, W. D., LARSON, A. M., DUCHELlE, A. E., RESOSUDARMO, I. A. P., HUYNH, T. B., AWONO, A., \& DOKKEN, T. (2014). How are REDD+ Proponents Addressing Tenure Problems? Evidence from Brazil, Cameroon, Tanzania, Indonesia, and Vietnam. World Development. https://doi.org/10.1016/j.worlddev.2013.01.013. 
- SUPARMOKO, M. (2016). Ekonomi Sumber Daya Alam dan Lingkungan. In Journal of Chemical Information and Modeling. https://oi.org/10.1017/ CBO9781107415324.004.

- WIJARJONO, A. (2015). Ekonometrika Dan Apikasinya (Fourth Edi). Yogyakarta: UPP STIM YKPN.

- WINARNO, W. W. (2011). Analisis Ekonometrika dan Statistika dengan Eviews. Edisi Ketiga. In UPP STIM YKPN. Yogyakarta. 